\title{
SIEMENVILJAN ITÄVYYTTÄ ALENTAVISTA TEKIJOISTÄ
}

\author{
Aarne Hilli \\ Valtion siementarkastuslaitos, Helsinki
}

Saapunut 12. 3. 1958 .

Siemenviljan itävyys vaihtelee melkoisesti eri vuosina. Vaihtelut johtuvat monista eri tekijöistä, joista suurin merkitys on sääsuhteilla, etenkin kasvukauden kosteus- ja lämpöoloilla.

Erilaisia itävyyttä alentavia seikkoja voidaan todeta jokaisen kasvukauden sadossa, mutta sääsuhteiltaan poikkeuksellisina vuosina niitä on tavallista enemmän tai jokin seikka muodostuu erityisen merkittäväksi.

Kesä 1955 oli maassamme lämpö- ja kosteussuhteiden puolesta verraten edullinen siementuotannolle. Siitä huolimatta todettiin valtion siementarkastuslaitoksessa siemenviljan itävyyden alentuneen - tosin suhteellisen vähän — sienitartunnan, puinti- ja kuivausvioitusten ym. seikkojen vuoksi.

Vuosi 1956 oli ankara hallavuosi, jonka vuoksi hallavauriot muodostuivat tärkeimmäksi viljan itävyyttä alentavaksi tekijäksi.

Kesä 1957, jonka satoa tämä tutkimus koskee, oli tyypillinen sadekesä. Kasvukauden alkujakso oli kohtalaisen edullinen, mutta loppukesä erittäin sateinen etenkin Lounais- ja Etelä-Suomessa. Kun lämpötila oli korjuukauden alkaessa korkea, johti se viljojen tähkäidäntään lakoutuneissa kasvustoissa, seipäillä ja kuhilailla.

Kesän 1957 sadossa ilmenivät vesivahingot sekä suoranaisina että välillisinä. Edellisistä oli luonteenomaisin jyvien ennenaikainen itäneisyys (tähkäidäntä),jälkimmäisistä kuivausvioitukset sekä homeisuus (primaariset Fusarium-homeet). Muina vikoina todettiin sadossa jyvien alkioiden särkyneisyyttä sekä vähäisessä määrin myös hallavaurioita.

Valtion siementarkastuslaitoksessa suoritettiin syksyn 1957 kuluessa tutkimus niistä viljasadossa todetuista seikoista, jotka olivat vaikuttaneet alentavasti siemenien itävyyteen. Tutkimukseen otettiin mukaan kaikki ne kevät- ja syysviljanäytteet, jotka tarkastettiin laitoksessa 1/9-31/12 1957 välisenä aikana. Näytteiden tarkastus suoritettiin yleisten siementarkastusohjeiden mukaisesti.

Suoritetussa tutkimuksessa on otettu terveiden siemenien ryhmään kaikki ne siemennäytteet, jotka ovat tarkastuksessa osoittautuneet pääosaltaan moitteettomiksi. Näytteet, joissa on vain vähäisessä määrin todettu itäneisyyttä, alkion sär- 


\begin{tabular}{|c|c|c|c|c|c|c|c|c|c|c|}
\hline \multirow{3}{*}{$\begin{array}{l}\text { Siemenlaji } \\
\text { Samenart }\end{array}$} & \multirow{3}{*}{$\begin{array}{l}\text { Näyte- } \\
\text { luku } \\
\text { yht. } \\
\text { Anzahl } \\
\text { Proben } \\
\text { Insges. }\end{array}$} & \multirow{3}{*}{$\begin{array}{c}\text { Itä- } \\
\text { vyys } \\
\text { kes- } \\
\text { kim. } \\
\% \\
\text { Keim- } \\
\text { fähigk. } \\
\text { Durch- } \\
\text { schn. }\end{array}$} & \multicolumn{4}{|c|}{$\begin{array}{l}\text { Terveet } \\
\text { Gesunde }\end{array}$} & \multicolumn{4}{|c|}{$\begin{array}{l}\text { Itäneet } \\
\text { Gekeimte }\end{array}$} \\
\hline & & & \multicolumn{2}{|c|}{$\begin{array}{c}\text { Näytteiden } \\
\text { lukumäärä } \\
\text { Anzahl } \\
\text { Proben }\end{array}$} & \multicolumn{2}{|c|}{$\begin{array}{l}\text { Näytteiden } \\
\text { itävyys } \\
\text { Keimfähigk. } \\
\text { d. Proben }\end{array}$} & \multicolumn{2}{|c|}{$\begin{array}{c}\text { Näytteiden } \\
\text { lukumäärä } \\
\text { Anzahl } \\
\text { Proben }\end{array}$} & \multicolumn{2}{|c|}{$\begin{array}{c}\text { Näytteiden } \\
\text { itävyys } \\
\text { Keimfähigk } \\
\text { d. Proben }\end{array}$} \\
\hline & & & $\begin{array}{l}\text { kpl } \\
\text { St. }\end{array}$ & $\%$ & $\begin{array}{l}\mathrm{kpl} \\
\text { St. }\end{array}$ & $\%$ & $\begin{array}{l}\text { kpl } \\
\text { St. }\end{array}$ & $\%$ & $\begin{array}{l}\text { kpl } \\
\text { St. }\end{array}$ & $\%$ \\
\hline Kaura & 4505 & 83.8 & 3950 & 87.7 & 3950 & 85.2 & 98 & 2.2 & 95 & 80.7 \\
\hline \multicolumn{11}{|l|}{ Hafer } \\
\hline \multicolumn{11}{|l|}{ Gerste, zweizeilig } \\
\hline \multicolumn{11}{|l|}{ Gerste, mehrzeilig } \\
\hline \multicolumn{10}{|l|}{ Sommerweizen } & 72.1 \\
\hline \multicolumn{10}{|l|}{ Winterweizen } & 74.7 \\
\hline $\begin{array}{l}\text { Ruis } \\
\text { Roggen }\end{array}$ & 233 & 77.6 & 93 & 39.9 & 93 & 81.2 & 124 & 53.2 & 118 & 78.5 \\
\hline
\end{tabular}

kyneisyyttä, homeisuutta, kuivausvioituksia tai hallan vaurioita, on laskettu terveisiin kuuluviksi. Vioittuneiden ryhmiin on otettu kaikki ne siemennäytteet, joissa kyseessä oleva vioitus on ollut runsasta sekä selvästi havaittavissa.

Tarkastettujen näytteiden lukumäärä sekä keski-itävyydet terveiden sekä viallisten osalta on esitetty taulukossa 1.

Tutkittuja näytteitä oli yhteensä 10 527. Graafisina piirroksina on esitetty näytteiden jakautuminen terveisiin sekä viallisiin.

Piirros 1 osoittaa kaksi- ja monitahoisen ohran siemenkelpoisuutta. Näytteistä on ollut suurin osa terveitä (kaksitahoisella $68.2 \%$, monitahoisella $79.1 \%$ ). Yleisin vika on ollut itäneisyys (kaksitahoisella ohralla $23.8 \%$, monitahoisella $13.2 \%$ ). Kuivauksen aiheuttamat vioitukset ovat olleet yleisempiä kaksitahoisella $(5.5 \%)$ kuin monitahoisella ohralla $(2.4 \%)$. Homeisuutta on ollut vähemmän kaksitahoisella $(0.9 \%)$ kuin monitahoisella ohralla $(2.1 \%)$. Alkion särkyneisyyttä on niinikään esiintynyt vähemmän kaksitahoisella $(1.8 \%)$ kuin monitahoisella ohralla $(3.4 \%)$. Hallan aiheuttamia vaurioita ei ohrassa todettu.

Piirroksesta 2 (kaura ja kevätvehnä) ilmenee, että kaurasadosta on pääosa ollut moitteetonta $(87.7 \%)$ kun sensijaan kevätvehnällä vain vajaa kolmannes $(30.7 \%)$ näytteistä on ollut terveitä. Itäneisyyttä on kaurassa ollut vain vähän $(2.2 \%)$, mutta kevätvehnässä sensijaan varsin runsaasti $(56.8 \%)$. Kuivausvioituksia on kaurassa ollut $6.4 \%$, kevätvehnässä lähes kahdenkertaisesti $(11.0 \%)$. Homeisten näytteiden osuus on ollut kauralla $2.6 \%$, kevätvehnällä huomattavasti suurempi $(10.7 \%)$. Alkion särkyneisyyttä on kauranäytteissä todettu vain vähän $(0.2 \%)$, 
Tabelle I. Ober die Faktoren von herabsetzender Wirkung auf die Keimfähigkeit des Saatguts 1/9 -31/12 1957

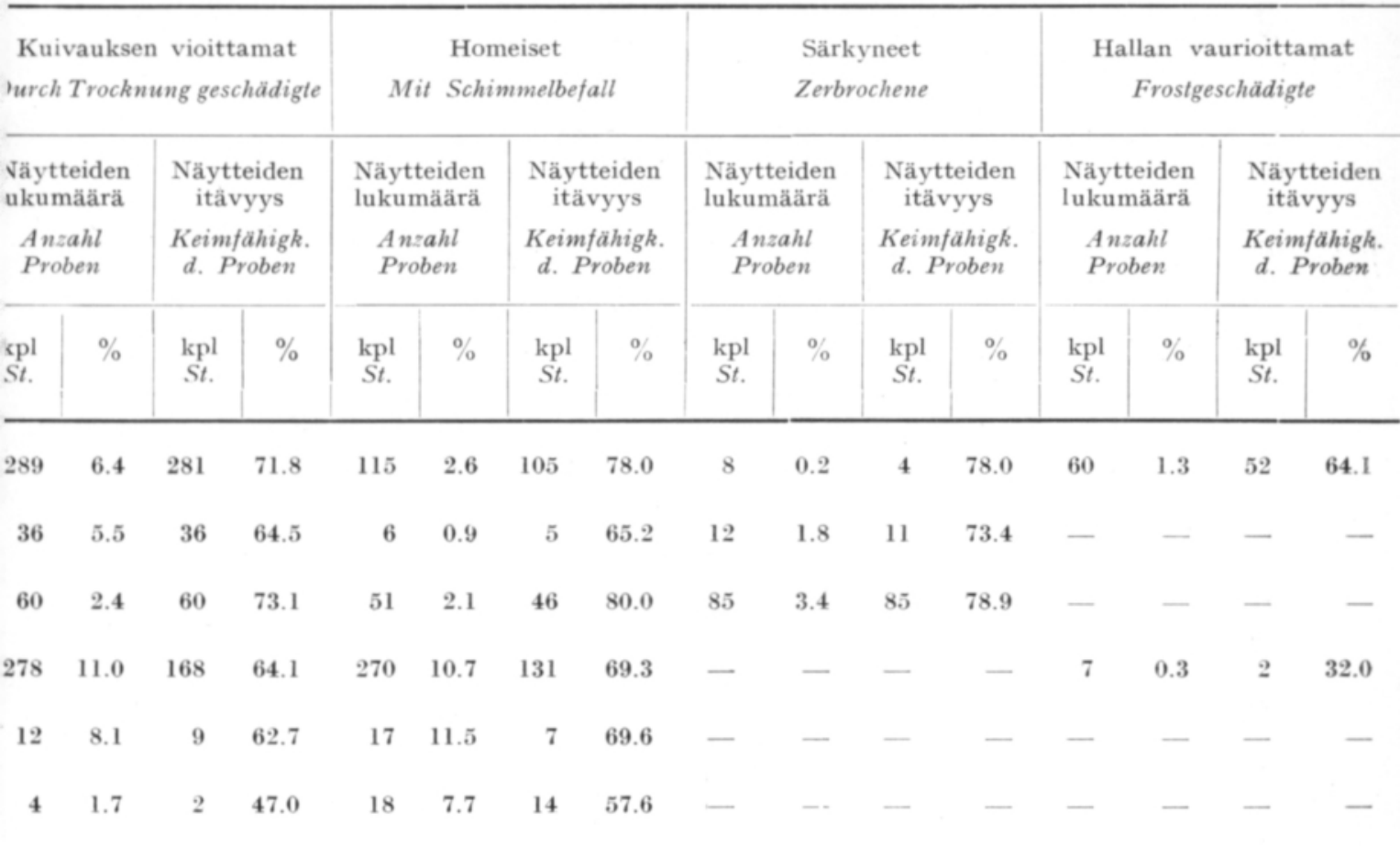

kevätvehnällä ei ollenkaan. Hallan aiheuttamia vioituksia oli kauranäytteissä $1.3 \%$, kevätvehnässä $0.3 \%$.

Syysviljanäytteistä oli (piirros 3) ainoastaan noin kolmannes moitteettomia (syysvehnästä $29.7 \%$, rukiista $39.9 \%$ ). Yli puolet sadosta oli ennenaikaisesti itäneitä (syysvehnällä $58.8 \%$, rukiilla $53.2 \%$ ). Kuivausvioituksia oli syysvehnällä $8.1 \%$ ja rukiilla $1.7 \%$. Homeisten näytteiden määrä oli syysvehnällä $11.5 \%$, rukiilla $7.7 \%$. Alkion särkyneisyyttä sekä hallan aiheuttamia vioituksia ei todettu syysviljoissa.

Ottamalla huomioon kaikki tutkitut siemennäytteet oli kesän 1957 viljasadosta tervettä $55.6 \%$, itänyttä $34.7 \%$, kuivauksessa vioittunutta $5.9 \%$, homehtunutta $5.9 \%$, särkynyttä $0.9 \%$ sekä hallan vaurioittamaa $0.3 \%$. Nämä luvut antavat yleiskuvan sadon laadusta huolimatta siitä, että niiden summa nousee vähän yli sadan $(103.3 \%)$. Ero johtuu siitä, että osassa näytteitä oli samanaikaisesti useampia vikoja (itäneisyys + kuivausvioitukset, homeisuus + hallavauriot j.n.e.), joten sama näyte jouduttiin ottamaan huomioon useampaan kertaan prosentteja laskettaessa.

Itävyyden alentuminen siemenissä ilmenneiden vikojen vuoksi tuli näkyville itävyysmäärityksissä.

Kaksitahoisesta ohrasta (piirros 5) itivät terveet siemennäytteet keskimäärin $79.1 \%$, itäneitä jyviä sisältäneet näytteet $76.1 \%$, alkion särkyneisyyttä sisältäneet näytteet $73.4 \%$, homeiset näytteet $65.2 \%$ sekä kuivausvioituksia sisältäneet näytteet $64.5 \%$. 


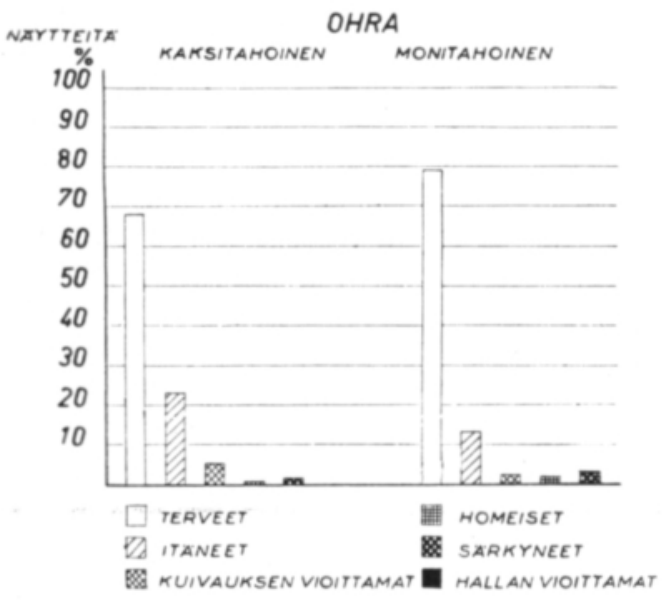

Piirros 1. - Diagramm 1.

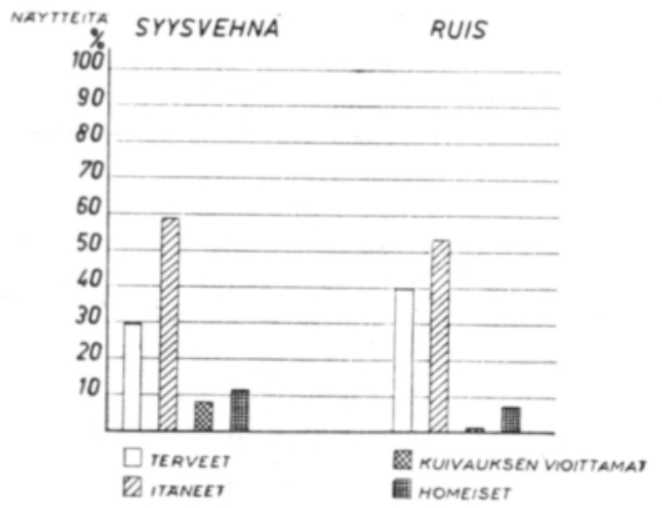

Piirros 3. - Diagramm 3.

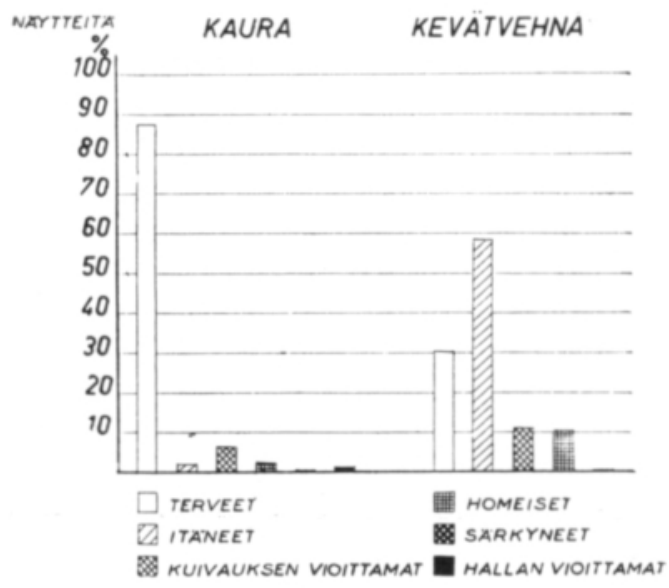

Piirros 2. - Diagramm 2.

Piirrokset $1-3$. Terveiden ja viallisten siemenerien osuus kaksi- ja monitahoisella ohralla (piirros 1), kauralla ja kevätvehnällä (piirros 2) sekä syysvehnällä ja rukiilla (piirros 3 ).

Diagramme 1-3. Anteil der gesunden bzw. geschädigten Saatposten bei zwei- und mehrzeiliger Gerste (Diagramm 1), bei Hafer und Sommerweizen (Diagramm 2) sowie bei Winterweizen und Roggen (Diagramm 3)

Monitahoisella ohralla (piirros 4) oli terveiden siemenerien keski-itävyys $86.9 \%$, itäneiden $83.1 \%$, homeisten $80.0 \%$, särkyneiden $78.9 \%$ sekä kuivauksessa vioittuneiden $73.1 \%$.

Kauranäytteistä (piirros 6) itivät moitteettomat keskimäärin $85.2 \%$, itäneet $80.7 \%$, homeiset $78.0 \%$, särkyneet $78.0 \%$, kuivauksen vioittamat $71.8 \%$ sekä hallan vaurioittamat $64.1 \%$.

Kevätvehnällä (piirros 7) itivät terveet näytteet keskimäärin $78.7 \%$, itäneet $72.1 \%$, homeiset $69,3 \%$ sekä kuivauksen vioittamat $64.1 \%$.

Syysvehnällä (piirros 8) oli moitteettomien siemennäytteiden keski-itävyys $82.6 \%$, itäneiden $74.7 \%$, homeisten $69.6 \%$ sekä kuivauksessa vioittuneiden $62.7 \%$.

Terveiden ruisnäytteiden (piirros 9) keski-itävyys oli $81.2 \%$, itäneiden $78.5 \%$ sekä homeisten $57.6 \%$.

Itävyys alentui tähkäidännän vuoksi vähemmän kuin muista syistä (kaksitahoisella ohralla ainoastaan $3.0 \%$, monitahoisella ohralla $3.8 \%$, kauralla $4.5 \%$, kevätvehnällä $6.6 \%$, syysvehnällä $7.9 \%$ ja rukiilla $2.7 \%$ ). 
MONITAHOINEN OHRA

\begin{tabular}{|l|}
\hline TERVEET \\
\hline ITANEET \\
\hline HOMEISET \\
\hline SARKYNEET \\
\hline RUIVAUKSEN VIOITTAMAT \\
\hline \\
\hline
\end{tabular}

Itävyys $10 \quad 2030<0 \quad 50 \quad 6070 \quad 80 \quad 90 \quad 100 \%$

Piirros 4. - Diagram 4.

KAURA

\begin{tabular}{|l|}
\hline TERVEET \\
\hline ITANEET \\
\hline HOMEISET \\
\hline \multicolumn{2}{|c|}{7} \\
\hline SARKYNEET \\
\hline KUIVAUKSEN VIOITTAMAT \\
\hline HALLAN VIOITTAMAT \\
\hline \\
\hline
\end{tabular}

Itävyys $10 \quad 2030 \quad 4050 \quad 6070 \quad 8090 \quad 100 \%$

Piirros 6. - Diagramm 6.

SYYSVEHNA

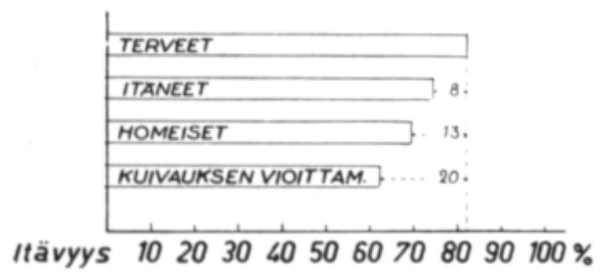

Piirros 8. - Diagramm 8.

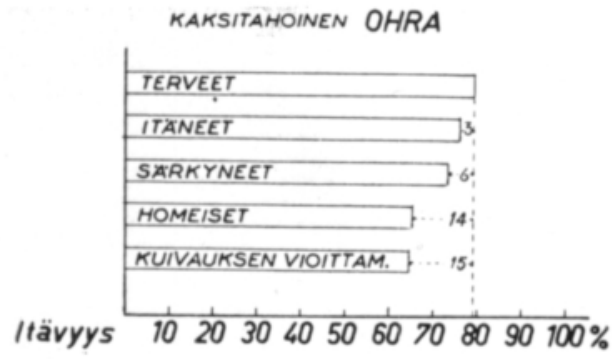

Piirros 5. - Diagramm 5.

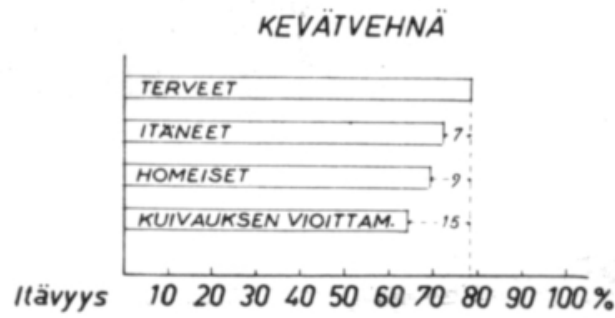

Piirros 7. - Diagramm 7.

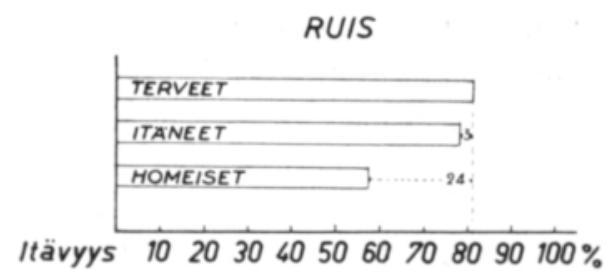

Piirros 9. - Diagramm 9.

Piịrrokset 4-9. Itävyysprosentin alentuminen siemenissä todettujen vikojen vuoksi monitahoisella ohralla (piirros 4), kaksitahoisella ohralla (piirros 5), kauralla (piirros 6), kevätvehnällä (piirros 7), syysvehnällä (piirros 8) sekä rukiilla (piirros 9).

Diagramme 4-9. Herabsetzung des Keimfähigkeitsprozents infolge der in der Saat festgestellten Schäden bei mehrzeiliger Gerste (Diagramm 4), zweizeiliger Gerste (Diagramm 5), Hafer (Diagramm 6), Sommerweizen (Diagramm 7), Winterweizen (Diagramm 8) und Roggen (Diagramm 9).

Alkion särkymisen vuoksi heikentyi itävyys enemmän kuin tähkäidännästä johtuen (kaksitahoisella ohralla $5.7 \%$, monitahoisella ohralla $8.0 \%$ ja kauralla $7.2 \%$ ). Kevät- ja syysvehnällä sekä rukiilla ei alkiosta rikkoutuneita siemeniä ollut. Jyvän palasia sisältäneitä näytteitä oli kevätvehnällä 9 ja niiden keski-itävyys $63.0 \%$, syysvehnällä 2 (keski-itävyys $87.0 \%$ ) sekä rukiilla 16 (keski-itävyys $80.6 \%$ ).

Homeisuus alensi itävyyttä vieläkin enemmän kuin jyvien särkyminen. Itävyyden heikentyminen oli kaksitahoisella ohralla $13.9 \%$, monitahoisella ohralla $6.9 \%$, ka uralla $7.2 \%$, kevätvehnällä $9.4 \%$, syysvehnällä $13.0 \%$ ja rukiilla $23.6 \%$. 


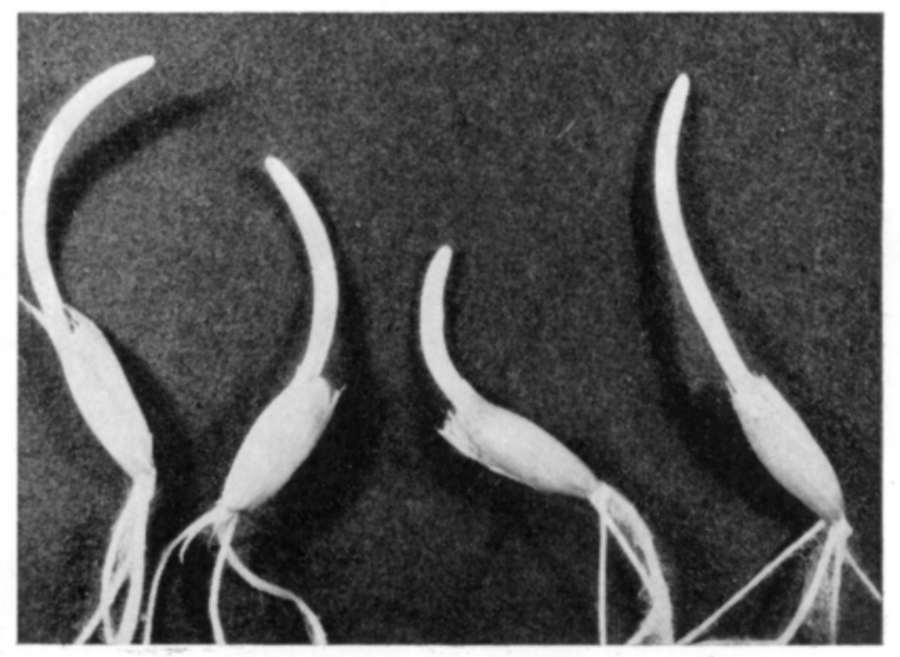

Kuva 1. Kauran terveitä ituja. Abb. 1. Gesunde Haferkeime.

Kuivausvioitusten itävyyttä alentava vaikutus oli edellistäkin suurempi (kaksitahoisella ohralla $14.6 \%$, monitahoisella ohralla $13.8 \%$, kauralla $13.4 \%$, kevätvehnällä $14.6 \%$, syysvehnällä $19.9 \%$ ja rukiilla (ainoastaan neljä näytettä) $34.2 \%$.

Halla alensi itävyyttä kaikkein enimmän. Hallavaurioita todettiin kuitenkin vain kauralla ja kevätvehnällä. Edellisellä ne heikensivät itävyyttä $21.1 \%$, jälkimmäisellä (ainoastaan seitsemän näytettä) $46.7 \%$.

\section{Tulosten tarkastelua}

Tutkituista 10527 siemennäytteestä oli suurin osa kauraa (4505 näytettä), kevätvehnää (2521) ja monitahoista ohraa (2470), pienempi osa kaksitahoista ohraa $(650)$, ruista (233) ja syysvehnää (148). Kaikkiaan vastasivat tarkastetut erät noin 40 miljoonan kilon suuruista siemenviljamäärää.

Kesän 1957 viljasadosta oli mainitun näytemäärän tutkimuksen perusteella yleensä moitteetonta, terveeksi katsottavaa (kuva 1) ainoastaan runsas toinen puoli $(55.6 \%)$. Yleisin vika oli korjuukauden sateisuudesta ja lämpimyydestä johtunut ennenaikainen itäneisyys $(34.7 \%$ eli noin kolmannes näytteistä). Homeisuutta ja kuivausvioituksia oli molempia samanverran (5.9\%). Harvinaisempia vikoja olivat alkion särkyneisyys $(0.9 \%)$ sekä hallan vauriot $(0.3 \%)$.

Itäneisyys oli runsaampaa kuorettomissa viljoissa (vehnä ja ruis) kuin kuorellisissa (ohra ja kaura). Kaikkein eniten tähkäidäntää oli syysvehnässä $(58.8 \%$ näytteistä), sitten kevätvehnässä $(56.8 \%)$, rukiissa $(53.2 \%)$, kaksitahoisessa ohrassa $(23.8 \%)$, monitahoisessa ohrassa $(13.2 \%)$ sekä vähiten kaurassa $(2.2 \%)$.

Homeisuus oli niinikään yleisempää kuorettomilla kuin kuorellisilla viljalajeilla. Kaikkein homeisinta oli syysvehnä (11.5\% näytteistä), senjälkeen kevätvehnä $(10.7 \%)$, ruis $(7.7 \%)$, kaura $(2.6 \%)$, monitahoinen ohra $(2.1 \%)$ sekä kaksitahoinen ohra $(0.9 \%)$. 


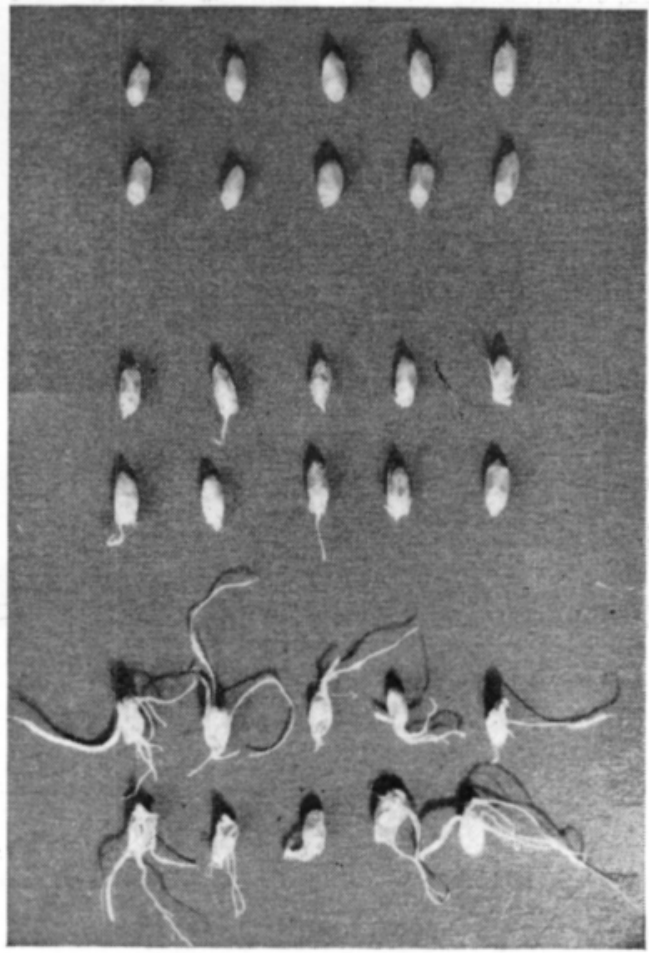

Kuva 2. Kevätvehnä. Itämättömiä jyviä (ylhäällä), lievää tähkăidäntää (keskellä) ja voimakasta tähkäidäntää (alhaalla).

Abb. 2. Sommerweizen. Keimfreie Körner (oben), mässiges Keimen in der Ahre (Mitte) und starkes Keimen in der Ahre (unten).

Kuivausvioituksia todettiin enimmän vehnissä (kevätvehnällä $11.0 \%$, syysvehnällä $8.1 \%$ näytteistä). Senjälkeen niitä oli runsaimmin kauralla $(6.4 \%)$, kaksitahoisella ohralla $(5.5 \%)$, monitahoisella ohralla $(2.4 \%)$ ja vähimmän rukiilla $(1.7 \%)$.

Alkion särkyneisyyttä ei todettu kuorettomissa viljoissa (syysviljat sekä kevätvehnä). Enimmin oli alkioista rikkoutuneita jyviä monitahoisessa ohrassa (3.4\% näytteistä), senjälkeen kaksitahoisessa ohrassa (1.8\%) sekä kaurassa $(0.2 \%)$.

Hallan aiheuttamia vaurioita oli ainoastaan kaurassa ja kevätvehnässä, edellisessä $1.3 \%$, jälkimmäisessä $0.3 \%$ näytteiden lukumäärästä.

Verrattaessa todettujen vikojen vaikutusta siemenien itävyyteen osoittautui, että yleisimpänä vikana esiintynyt viljojen ennenaikainen itäneisyys (tähkäidäntä) alensi lopullista itävyyttä suhteellisen vähän $(2.7-7.9 \%)$ ja vähemmän kuin muut siemenen viat. Tämä yllättävä ja käytännöllisesti tärkeä tulos johtuu ilmeisesti siitä, että siemenien pysähtynyt itäminen voi jatkua jos siitä kehittynyt itu on lyhyt ja vahingoittumaton. Tästä on merkkinä itujen vaalea tai vihertävä väri sekä kirkas pinta. Jos siemenestä kehittynyt itu sensijaan on tummentunut, ruskea tai homeessa etenkin juuristaan, ei siemen enää idä. Tutkitut siemennäytteet olivat pääosaltaan kauppasiementä, joka on puinnin jälkeen kuivattu sekä lajiteltu. Pit- 


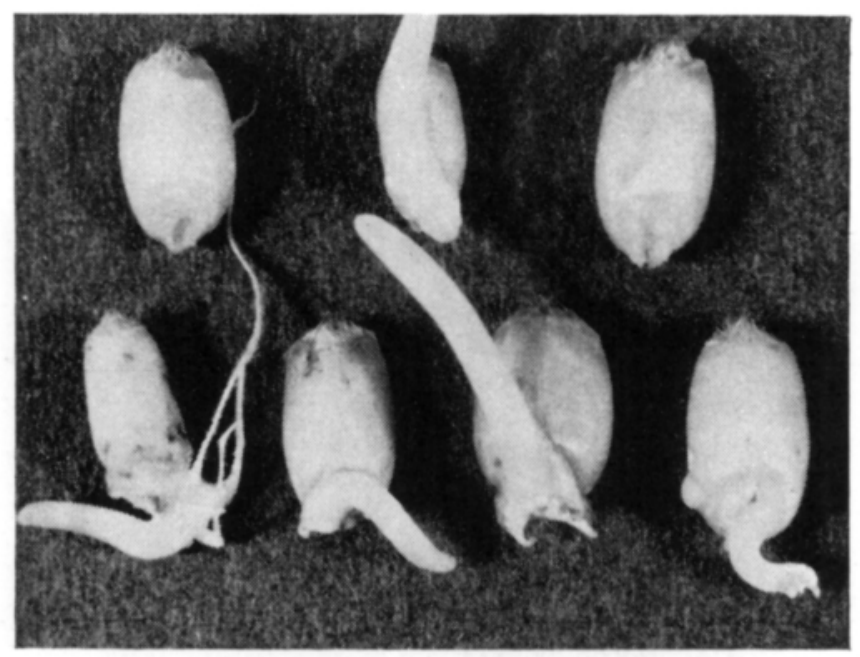

Kuva 3. Vehnän jyviä, jotka ovat puinnissa tapahtuneen alkion särkymisen vuoksi kehittäneet vaillinaisia, elinkelvottomia ituja.

Abb. 3. Weizenkörner, die infolge von zerbrochener Keimanlage unvollständige, nicht lebenstaugliche Keime erzeugt haben.

källe itäneet jyvät joutuvat näinollen käsittelyn kestäessä muusta sadosta eroon ja ainoastaan itämisen alulla olevat voivat päästä lajiteltuun, siemeneksi aiottuun viljaerään (kuva 2).

Eri viljalajeista alentui itävyys tähkäidännän vuoksi enimmän syysvehnällä $(7.9 \%)$, senjälkeen kevätvehnällä $(6.6 \%)$, kauralla $(4.5 \%)$, monitahoisella ohralla $(3.8 \%)$, kaksitahoisella ohralla $(3.0 \%)$ ja vähimmän rukiilla $(2.7 \%)$.

Jyvien alkioiden särkyminen johtuu useimmiten liian ankarasta puinnista. Ohraa puitaessa vihneenkatkoja myös usein rikkoo jyviä. Jos puinti tai muu viljan käsittely on vioittanut jyvän alkiota, ei jyvä idä tai on kehittynyt itu puutteellinen. Tavallisesti on tällöin idun varsiosa terve, mutta juuret puuttuvat, koska juurien aiheet ovat puinnissa vahingoittuneet tai hankautuneet pois (kuva 3).

Suoritetussa tutkimuksessa todettiin alkioiden särkyneisyyttä ainoastaan kuorellisilla viljoilla. Itävyyden alentuminen oli suurin monitahoisella ohralla $(8.0 \%)$, senjälkeen kauralla (7.2\%) sekä kaksitahoisella ohralla (5.7\%). Alkioiden rikkoutumisen aiheuttama itävyyden heikentyminen oli suurempi kuin tähkäidännän vastaava vaikutus.

Homeisuus on kylvösiemenessä yleistä etenkin sateisten kasvu- ja korjuukausien jälkeen. Tutkitussa sadossa tavatut homeet olivat pääasiassa Fusarium-sienten aiheuttamia. Homeisista siemenistä kasvavat idut ovat vaillinaisia. Niissä ei kehity itua suojaavaa tuppea tai on itutuppi rikkinäinen, josta johtuen jyvä ei kykene kasvattamaan orasta maan pintaan vaikka se itäisikin (kuva 4).

Tutkitussa viljassa homeisuus alensi itävyyttä enimmän rukiilla (23.6\%), senjälkeen kaksitahoisella ohralla $(13.9 \%)$, syysvehnällä $(13.0 \%)$, kevätvehnällä $(9.4 \%)$, kauralla $(7.2 \%)$ sekä vähimmän monitahoisella ohralla $(6.9 \%)$. Itävyyden alentuminen oli homeisuuden vuoksi vieläkin suurempi kuin alkioiden särkymisestä johtuen. 


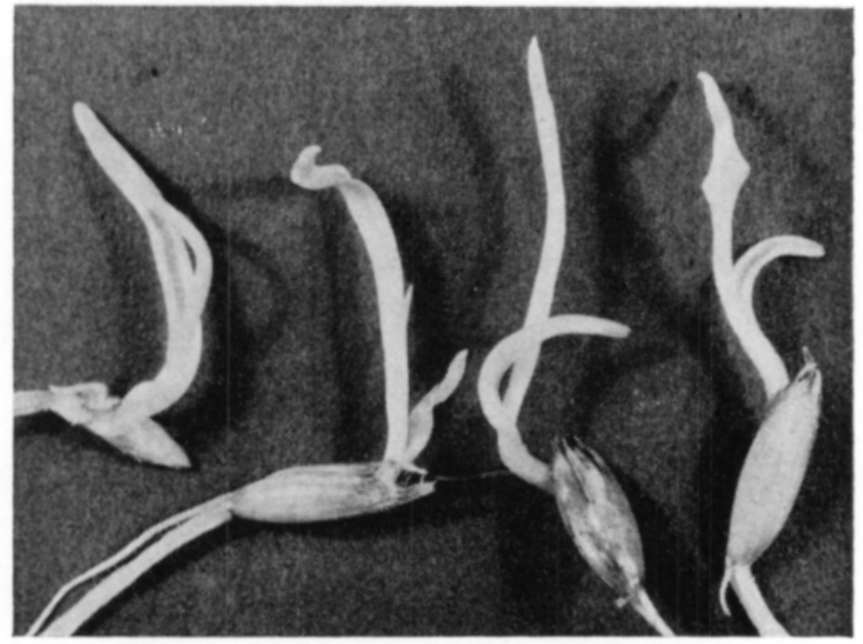

Kuva 4. Homesienten aiheuttamia, sairaita, kuolleiksi arvosteltavia kauran ituja. Abb. 4. Durch Schimmelbefall kranke, als tot zu bewertende Haferkeime.

Kuivausvioitukset ovat luonnollisesti sateisen korjuukauden jälkeen tavallista yleisempiä. Kun epäedullisten olosuhteiden vallitessa joudutaan kuivattamaan suuria viljamääriä, tullaan käyttäneeksi liian nopeata kuivausta sekä liian korkeata kuivauslämpöä.

Suoritetussa tutkimuksessa tulivat näkyville viljan polttovioituksen seuraukset idätyskokeissa. Vioittuneista jyvistä kasvaa ituja, joihin ei kehity lainkaan tai ainoastaan vähän juurikarvoja. Tyypillistä polttovioitukselle on, että itutuppi ei kasva ylöspäin kuten terveillä siemenillä, vaan käyristyy jyvän pintaa kohden ja irtaantuu helposti juuren ja tupen yhtymäkohdasta (kuva 5).

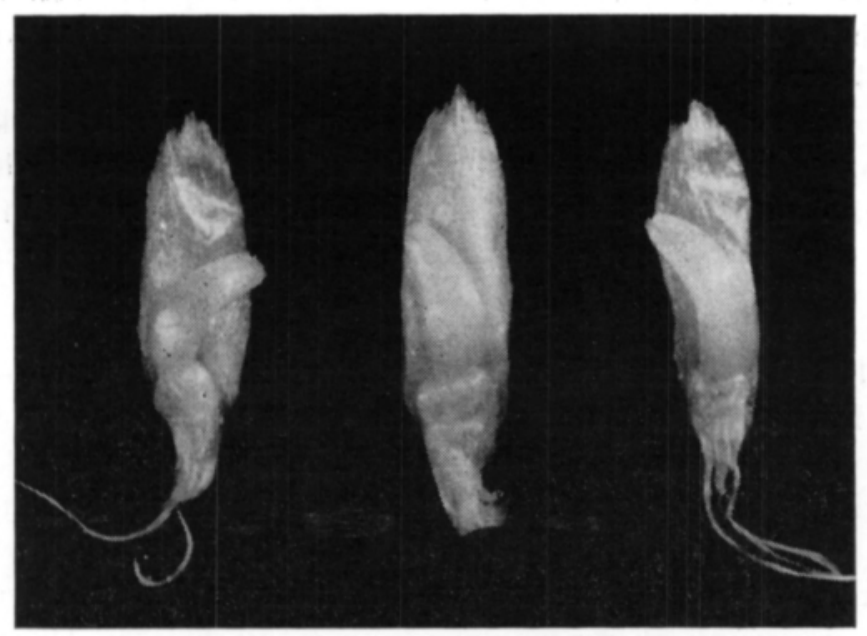

Kuva 5. Liian korkean kuivauslämmön turmelemia vehnän jyviä, joissa itutuppi on jäänyt lyhyeksi ja käyristynyt jyvän pintaa kohden.

$A b b$. 5. Durch übermässig hohe Trocknungstemperatur verdorbene Weizenkörner, bei denen die Keimhülle kurz geblieben ist und sich gegen die Oberfläche des Korns krümmt. 


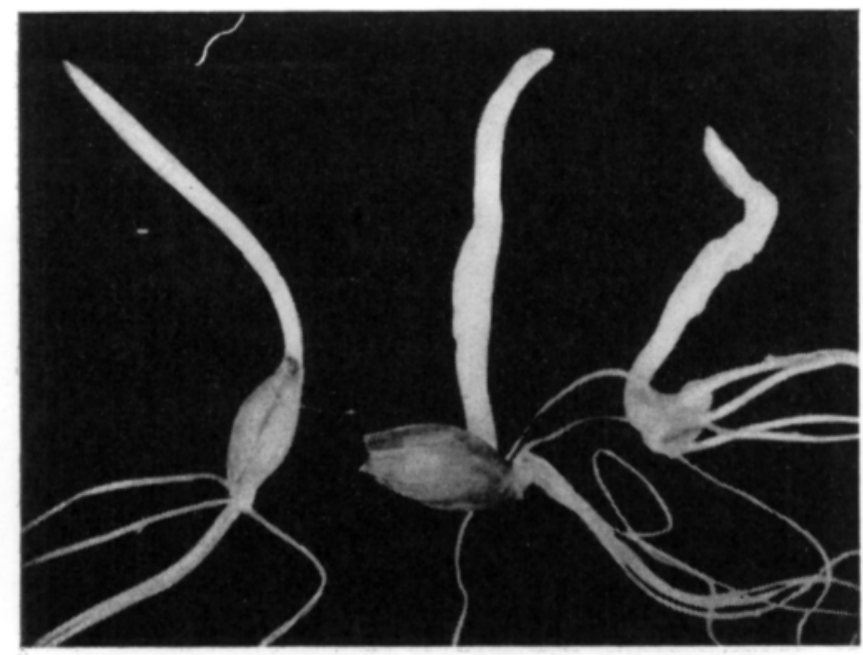

Kuva 6. Terve ,kapea ja vihreä ohran itu (vasemmalla) sekä kaksi hallojen vioittamaa itua, jotka ovat pöhöttyneitä, mutkaisia ja lehtivihreättömiä.

Abb. 6. Gesunder, schmaler und grïner Gerstenkeim (links), sowie zwei von Frostnächten geschädigte aufgeschwollene, winklige und chlorophyllose Keime.

Kuivausvioitukset alensivat itävyyttä eniten rukiilla $(34.2 \%)$, sitten syysvehnällä $(19.9 \%)$, kevätvehnällä sekä kaksitahoisella ohralla $(14.6 \%)$, monitahoisella ohralla $(13.8 \%$ ) ja vähiten kauralla $(13.4 \%)$. Kuivausvioitusten merkitys itävyydelle osoittautui edellä esitettyjä muita vikoja suuremmaksi.

Kesän 1957 aikana ei halloja sanottavasti esiintynyt. Siitä johtuen hallavaurioita siemenissä todettiin vain vähän. Hallan aiheuttama vioitus tulee idätyskokeessa näkyville siten, että itäneiden jyvien itutuppi kasvaa suureksi ja pöhöttyneeksi tai on kyhmyinen ja mutkainen. Oraslehdet itutupen sisässä ovat värittömiä tai ei niitä kehity ensinkään. Juurikarvojen muodostuminen on myös normaalia vähäisempää (kuva 6).

Hallan vioitus saattaa heikentää viljan itävyyttä suuresti. Tutkitussa sadossa todettiin hallavaurioita vain kaurassa ja kevätvehnässä, mutta alensivat ne itävyyttä enemmän kuin muut tekijät (kauralla $21.1 \%$, kevätvehnällä $46.7 \%$ ).

\section{$P \ddot{a} \ddot{a} t$ e $l m \ddot{a} t$}

Syksyllä 1957 korjatussa viljasadossa oli sen itämiskykyä arvostellen yleisimpinä vikoina korjuukauden sateisuudesta aiheutuneet vesivahingot, jotka olivat luonteeltaan joko suoranaisia (itäneisyys) tai välillisiä (homeisuus ja kuivausvioitukset). Muita vikoja (hallavauriot sekä alkion särkyneisyys) esiintyi suhteellisen vähän.

Itäneisyyttä ilmeni runsaimmin syys- ja kevätvehnässä sekä rukiissa. Kaksitahoisen ohran itäneisyys oli runsaampaa kuin monitahoisen. Kaura kärsi tähkäidännästä kaikkein vähimmin.

Homeisuus oli niinikään yleisintä syys- ja kevätvehnässä sekä rukiissa. Kaurassa oli homeen tartuntaa enemmän kuin ohrissa. 
Kuivausvaurioita todettiin runsaimmin kevät- ja syysvehnissä. Kaurassa ne olivat yleisempiä kuin ohrassa. Rukiissa esiintyi kuivausvioituksia vain vähän.

Puinnista ja käsittelystä johtunutta jyvän alkioiden särkyneisyyttä oli enimmän monitahoisessa ohrassa, vähemmän kaksitahoisessa ohrassa sekä kaurassa. Jyvän palasia sisältäneitä näytteitä oli runsaimmin rukiilla, vähemmän kevät- ja syysvehnällä.

Hallavaurioita todettiin vain vähän kaurassa sekä kevätvehnässä.

Tähkäidäntä alensi viljojen lopullista itävyyttä suhteellisen vähän ja vähemmän kuin muut siemenien viat. Enimmän tähkäidäntä heikensi itävyyttä syys- ja kevätvehnällä, senjälkeen kauralla, ohrilla ja rukiilla.

Jyvien alkioiden särkyminen alensi itävyyttä enemmän kuin tähkäidäntä. Itävyyden heikentyminen oli suurinta monitahoisella ohralla, vähän pienempää kauralla seká kaksitahoisella ohralla.

Kylvösiemenen primaariset homeet heikensivät itävyyttä edellisiä enemmän. Itävyyden alentuminen oli voimakkainta rukiilla, senjälkeen kaksitahoisella ohralla, syys- ja kevätvehnällä, kauralla sekä monitahoisella ohralla.

Kuivausvioitusten merkitys viljan itävyyden alentajana oli sateisen korjuukauden vuoksi erityisen suuri. Kuivausvirheet alensivat itävyyttä edellä esitettyjä voimakkaammin. Eniten alentui itävyys tästä syystä rukiilla, sitten vehnillä sekä ohrilla ja vähiten kauralla.

Hallan aiheuttamat vauriot alensivat itävyyttä enemmän kuin muut itävyyteen vaikuttaneet tekijät. Hallavioitukset, joita todettiin vain kevätvehnässä ja kaurassa, olivat ankarampia ensin mainitussa viljassa.

\section{REFERAT:}

UBER DIE FAKTOREN VON HERABSETZENDER WIRKUNG AUF DIE KEIMFÄHIGKEIT DES SAATGUTS

von

Aarne Hilli

Staatliche Samenkontrollanstalt, Helsinki

Der Herbst 1957 war ausserordentlich regnerisch, weshalb die Keimfähigkeit des Saatguts vor allem durch verschiedenartige Wasserschädigung beeinträchtigt wurde, die ihrem Charakter nach entweder unmittelbar (vorzeitiges Keimen) oder mittelbar wirkend war (Trocknungsschädigung und Schimmelbefall). Sonstige Schäden (Frostschädigung und Bruchsamen) kamen verhältnismässig wenig vor.

Von den untersuchten 10.257 Saatproben bestanden 4505 Proben aus Hafer, 2521 aus Sommerweizen, 2470 aus mehrzeiliger Gerste, 650 aus zweizeiliger Gerste, 233 aus Roggen und 148 aus Winterweizen. Insgesamt entsprachen die untersuchten Posten einer Saatgutmenge von etwa 40 Millionen kg.

Beim Vergleich der Einwirkungen der festgestellten Schäden auf die Keimfähigkeit der Samen erwies es sich, dass das als häufigster Fehler aufgetretene vorzeitige Keimen der Saaten (Keimen in der Ähre) die endgültige Keimfähigkeit in verhältnismässig geringem Mass herabsetzte (bei Winterweizen um $7.9 \%$, Sommerweizen $6.6 \%$, Hafer $4.5 \%$, mehrzeiliger Gerste $3.8 \%$, zweizeiliger Gerste $3.0 \%$ und Roggen $2.7 \%$ ).

Durch zerbrochene Keimanlage wurde die Keimfähigkeit bei mehrzeiliger Gerste um $8.0 \%$, bei Hafer um $7.2 \%$ und bei zweizeiliger Gerste um $5.7 \%$ herabgesetzt. 
Schimmelbefall (Fusarium sp.) setzte die Keimfähigkeit bei Roggen um $23.6 \%$ herab, bei zweizeiliger Gerste um $13.9 \%$, bei Winterweizen um $\mathbf{1 3 . 0} \%$, Sommerweizen $9.4 \%$, Hafer $7.2 \%$ und mehrzeiliger Gerste $6.9 \%$.

Trocknungsschädigungen bewirkten eine Herabsetzung der Keimfähigkeit bei Roggen um $34.2 \%$, Winterweizen $19.9 \%$, Sommerweizen und zweizeiliger Gerste 14.6\%, mehrzeiliger Gerste $13.8 \%$ und Hafer $13.4 \%$.

Frostschädigung wurde nur bei Hafer und bei Sommerweizen festgestellt, jedoch wurde durch dieselbe die Keimfähigkeit stärker als durch anderweitige Faktoren herabgesetzt (bei Hafer um $21.1 \%$ und bei Sommerweizen um 46,7\%). 